\title{
Antimicrobial and Anti-Inflammatory Activity of Some Lathyrus L. (Fabaceae) Species Growing in Turkey
}

\section{Türkiye'de Yetişen Bazı Lathyrus L. (Fabaceae) Türlerinin Antimikrobiyal ve Antienflamatuvar Aktivite Değerlendirilmesi}

\author{
。 \\ (D) Mehmet TEKIN4, (D) Tülay ÇOBAN3 \\ 1Ankara University, Faculty of Pharmacy, Department of Pharmacognosy, Ankara, Turkey \\ ${ }^{2}$ Ankara University, Faculty of Pharmacy, Department of Pharmaceutical Microbiology, Ankara, Turkey \\ ${ }^{3}$ Ankara University, Faculty of Pharmacy, Department of Pharmaceutical Toxicology, Ankara, Turkey \\ ${ }^{4}$ Cumhuriyet University, Faculty of Pharmacy, Department of Pharmaceutical Botany, Sivas, Turkey
}

\begin{abstract}
Objectives: The present study aimed to evaluate the antimicrobial and anti-inflammatory activities of methanol extracts and n-hexane, ethyl acetate, chloroform, and water fractions of five Lathyrus species, namely Lathyrus armenus, Lathyrus aureus, Lathyrus cilicicus, Lathyrus laxiflorus subsp. laxiflorus, and Lathyrus pratensis, growing in Turkey.

Materials and Methods: The antimicrobial activities were screened against Staphylococcus aureus ATCC 29213, Bacillus subtilis ATCC 6633, Escherichia coli ATCC 25922, Pseudomonas aeruginosa ATCC 27853, and Candida albicans ATCC 10231. Broth dilution was used to determine the antimicrobial activities of extracts and fractions. In vitro anti-inflammatory activity of these extracts and fractions was determined using human red blood cell membrane stabilization.

Results: The results demonstrated that ethyl acetate fractions of the tested species exhibited higher antimicrobial activity than the other extracts. Among all of the tested extracts and fractions, the highest anti-inflammatory activity was detected in water fractions. Furthermore, water fractions of $L$. pratensis showed better anti-inflammatory activity than acetylsalicylic acid and diclofenac sodium, which were used as standard drugs in this assay.

Conclusion: The results indicate the membrane stabilizing effect of the various extracts and fractions of the Lathyrus species and could constitute preliminary work for in vivo anti-inflammatory activity experiments.
\end{abstract}

Key words: Anti-inflammatory activity, antimicrobial activity, human red blood cell membrane, Lathyrus

öz

Amaç: Bu çalıșmada Türkiye yetişen beş Lathyrus türü, Lathyrus armenus, Lathyrus aureus, Lathyrus cilicicus, Lathyrus laxiflorus subsp. laxiflorus ve Lathyrus pratensis türlerinin metanollü ekstreleri ve hekzan, etil asetat, kloroform ve su fraksiyonlarının antimikrobiyal ve anti-enflamatuvar aktivitesi değerlendirilmiştir.

Gereç ve Yöntemler: Ekstrelerin ve fraksiyonların antimikrobiyal aktivitesi Staphylococcus aureus ATCC 29213, Bacillus subtilis ATCC 6633, Escherichia coli ATCC 25922, Pseudomonas aeruginosa ATCC 27853 ve Candida albicans ATCC 10231 suşlarına karşı değerlendirilmiştir. In vitro anti-enflamatuvar etki ise insan kırmızı kan hücresi kullanarak membran stabilizasyon yöntemi ile değerlendirilmiștir.

Bulgular: Etil asetatlı fraksiyonlar diğer ekstre ve fraksiyonlara göre daha yüksek antimikrobiyal aktivite, sulu fraksiyonlar ise diğer ekstre ve fraksiyonlara göre daha yüksek anti-enflamatuvar aktivite göstermiștir. Ayrıca, L. pratensis'in su fraksiyonu, standart olarak kullanılan asetilsalisilik asit ve diklofenak sodyumdan daha yüksek anti-enflamatuvar aktivite göstermiştir.

Sonuç: Elde edilen sonuçlara göre Lathyrus türlerinin ekstreleri ve fraksiyonlarının membran stabilizasyon aktiviteye sahip olup, ve in vivo antienflamatuvar aktivite deneyleri için bir ön çalıșma olabileceğini belirtmiştir.

Anahtar kelimeler: Anti-enflamatuvar aktivite, antimikrobiyal aktivite, insan kırmızı kan hücresi membran, Lathyrus

*Correspondence: E-mail: gulcin.saltan@pharmacy.ankara.edu.tr, Phone: +90 3122033088

Received: 13.02.2018, Accepted: 03.05.2018

๑Turk J Pharm Sci, Published by Galenos Publishing House. 


\section{INTRODUCTION}

Lathyrus L. is one of the largest genera in the family Fabaceae, with about 160 species distributed worldwide.' Turkey has a rich diversity of the genus Lathyrus, with 65 species and 75 taxa. $^{2}$

Secondary metabolites that have been found in plants, such as tannins, terpenoids, alkaloids, and flavonoids, have extensively different bioactive properties. Antibiotics are commonly used in fighting against bacterial infections and have been profoundly effective in terms of human health and quality of life since their invention. ${ }^{3}$ However, because of the appearance of resistance to antibiotics and some toxic products that resulted due to their consumption in recent decades antibiotics have become less effective against certain illnesses. Therefore, antibacterial agents derived from natural sources have started to play a significant role in the prevention and treatment of infection diseases. ${ }^{4}$ Plant extracts have become established as a source of many applications, including raw and processed food preservation, pharmaceuticals, alternative medicine, and natural therapies. ${ }^{5}$

Inflammation is a protective mechanism of living organisms against abnormal stimulation. It is a complex series of biochemical activities performed by the body in response to injury or abnormal stimulation caused by a physical, chemical, or biological agent. In general, generation of cytokines is considered to play a major role in inducing inflammatory process, and free radicals can propagate inflammation by stimulating release of proinflammatory cytokines such as interleukin$1 \beta$, interleukin-6, and tumor necrosis factor- $\alpha .{ }^{6}$ Drugs that are currently used for treatment of inflammatory conditions are nonsteroidal anti-inflammatory drugs (NSAIDs) and corticosteroids. NSAIDs inhibit the synthesis of prostaglandins and thromboxane inflammatory mediators by deactivating cyclooxygenase (COX), COX-1 and COX-2 enzymes. Some of these drugs such as aspirin, diclofenac, ketorolac, naproxen, and piroxicam have toxic effects such as risk of gastrointestinal bleeding. ${ }^{7,8}$

Moreover, the generation of oxygen free radicals is known to be involved in the development of the inflammatory process. These radicals are highly reactive molecules with an unpaired electron that can initiate radical chain reactions, leading to damage or destruction of the normal function of a living cell, and consequently causing many different diseases such as neurodegenerative disorders, cancer, cardiovascular diseases, atherosclerosis, diabetes, cataracts, and inflammation., ${ }^{9} 10$ In addition, inflammation caused by oxidative stress is the origin of many human diseases.

The potential harmful effects of free radicals are usually controlled by endogenous antioxidant mechanisms present in the cells. These mechanisms include cellular enzymes such as superoxide dismutase, catalase, glutathione peroxidase, and other defensive mechanisms, involving antioxidants, such as ascorbic acid, a-tocopherol, and glutathione. In biological systems antioxidant agents show their effects by different mechanisms including electron donation, metal ion chelation, co-antioxidants, or by gene expression regulation.11,12 Reactive oxygen species such as hydroxyl radicals, superoxide anions, and peroxynitrite radicals cause cellular damage by destroying cellular biomolecules such as nucleic acids, proteins, carbohydrates, and lipids, which results in inflammation. Therefore, compounds with radical scavenging activities may be expected to have anti-inflammatory properties. ${ }^{13}$ Current anti-inflammatory drugs essentially have become ineffective for long-term protection since they have unexpected side effects. Hence, new plants and herbal compounds with antiinflammatory properties are investigated in order to discover more effective compounds and avoid the toxic effects of antiinflammatory drugs.

Radical scavenging activities of phenolic and polyphenolic compounds, which are secondary metabolites in plants, were shown in previous studies. There are many studies on the anti-inflammatory activity of plant extracts and secondary metabolites such as flavonoids. ${ }^{14,15}$

The aim of the present study was to evaluate the total flavonoid contents and the antimicrobial and anti-inflammatory activities of methanol extracts and $n$-hexane, chloroform, ethyl acetate, and water fractions of the aerial parts of Lathyrus armenus (Boiss\&Huet) Sirj, Lathyrus aureus (Stev.) Brandza, Lathyrus cilicicus Hayek\&Siehe, Lathyrus laxiflorus (Desf.) O. Kuntze subsp. laxiflorus, and Lathyrus pratensis L. growing in Turkey. Among these species, $L$. armenus and $L$. cilicicus are endemic for Turkey. There are no previous reports dealing with the antiinflammatory activities of the five examined Lathyrus species.

The study protocol was approved by the ethics committees of the Faculty of Medicine of Ankara University, Ankara, Turkey (26.10.2015/16-695-15).

\section{MATERIALS AND METHODS}

\section{Chemical material}

The solutions, acetylsalicylic acid, sodium chloride, and Mueller Hinton Broth were purchased from Merck (Germany), Sigma-Aldrich (USA), Riedel-de Haën (Germany), and Difco Laboratories (USA), respectively.

\section{Instruments}

Absorbance was measured by SpectraMax 190 Microplate Reader (SpectraMax Molecular Devices Inc, USA); the centrifugation was carried out by Sigma 4K15 10740 and vortexing by Labinco L46 (Netherlands).

\section{Plant material}

The aerial parts of L. armenus, L. aureus, L. cilicicus, L. laxiflorus subsp. laxiflorus, and L. pratensis were collected and identified by Dr. M. Tekin. Voucher specimens were deposited in Ankara University, Faculty of Pharmacy, Kamil Karamanoğlu Herbarium (AEF). Data for the collected species are given in Table 1.

\section{Preparation of extracts}

The obtained plants were dried and powdered. Then $20 \mathrm{~g}$ of plant material was extracted separately with methanol using a Soxhlet apparatus over $24 \mathrm{~h}$. The solvent was evaporated 
under reduced pressure and dissolved in water and partitioned with $n$-hexane, chloroform, and ethyl acetate, in that order. All extracts were dried and stored at $4^{\circ} \mathrm{C}$.

In vitro antibacterial and antifungal activity of Lathyrus species Methanol extracts and $n$-hexane, chloroform, ethyl acetate, and water fractions from the aerial parts of five Lathyrus species were investigated for their potential in vitro antibacterial activities against Staphylococcus aureus ATCC 29213, Bacillus subtilis ATCC 6633, Escherichia coli ATCC 25922, and Pseudomonas aeruginosa ATCC 27853 and antifungal activity against Candida albicans ATCC 10231. Stock solution was prepared by dissolving $4 \mathrm{mg}$ of the methanol crude extract and water fraction in $70 \%(\mathrm{v} / \mathrm{v})$ methanol and in water, respectively, and chloroform, ethyl acetate, and $n$-hexane fractions in $20 \%$ $(v / v)$ dimethyl sulfoxide. A broth dilution assay was used for determination of the minimum inhibitory concentration (MIC). The cultures were obtained in Mueller Hinton Broth; serial two-fold dilutions ranging from 1.000 to $0.0625 \mathrm{mg} / \mathrm{mL}$ were prepared in the medium. A series of tubes containing only inoculated broth were used as controls. After incubation for 18-24 $\mathrm{h}$ at $37 \pm 1^{\circ} \mathrm{C}$ for bacteria and $48 \mathrm{~h}$ for fungi, the last tube with no microbial growth was recorded to represent MIC value $(\mathrm{mg} / \mathrm{mL}){ }^{16,17}$

\section{Total flavonoid content}

The extracts and fractions $(2 \mathrm{mg} / \mathrm{mL}$ ) were placed in a $3 \mathrm{~mL}$ test tube. Then distilled water was added to the test tube to make it up to $1.5 \mathrm{~mL}$ and then it was vortexed. After that, $0.075 \mathrm{~mL}$ of $\mathrm{NaNO}_{2} 5 \%(\mathrm{w} / \mathrm{v})$ was added, it was vortexed again, and then left for $5 \mathrm{~min}$. Next, $0.15 \mathrm{~mL}$ of $\mathrm{AlCl}_{3} 10 \%(\mathrm{w} / \mathrm{v})$ was added to the tube. After $6 \mathrm{~min}, 0.5 \mathrm{~mL}$ of $1 \mathrm{M} \mathrm{NaOH}$ was added to the mixture. Then the final volume was made up to $3 \mathrm{~mL}$ with distilled water. This mixture was vortexed and the absorbance was measured against a blank at $510 \mathrm{~nm}$. Quercetin was used as standard for the calibration curve. The flavonoid content was calculated by using the quercetin calibration equation. ${ }^{18}$

$A=0.0245 C-0.0417, r^{2}=0.9834$

A: Absorbance

C: Flavonoid content ( $\mu \mathrm{g} / \mathrm{mg})$

\section{Anti-inflammatory assay}

Preparation of the human red blood cell suspension

Fresh whole blood was collected from healthy volunteers

Table 1. Collection data of the examined Lathyrus species

\begin{tabular}{lll} 
Species & Collection location & AEF no. \\
\hline Lathyrus armenus & Sivas (M. Tekin 1278) & 26680 \\
\hline Lathyrus aureus & Sivas (M. Tekin 1277) & 26684 \\
\hline Lathyrus cilicicus & Karaman (M. Tekin 1210) & 26681 \\
\hline $\begin{array}{l}\text { Lathyrus laxiflorus subsp. } \\
\text { laxiflorus }\end{array}$ & Sivas (M. Tekin 1274) & 26682 \\
\hline Lathyrus pratensis & Sivas (M. Tekin 1273) & 26683 \\
\hline
\end{tabular}

who had not taken any anti-inflammatory or steroidal drug for 2 weeks before the experiment and it was transferred to centrifuge tubes. The tubes were subjected to centrifugation at $3000 \mathrm{rpm}$ for $10 \mathrm{~min}$. The supernatant part of the tubes was decanted and the precipitated part was washed three times with an equal volume of isosaline $(0.85 \%, \mathrm{pH} 7.2)$. The volume of the blood was measured and reconstituted as $10 \% \mathrm{v} / \mathrm{v}$ suspension with isosaline.

\section{Heat-induced hemolysis}

The reaction mixture $(2 \mathrm{~mL})$ consisted of $1 \mathrm{~mL}$ of test sample (methanol extract, water, ethyl acetate, chloroform, and $n$-hexane fractions) and $1 \mathrm{~mL}$ of $10 \%$ RBC suspension; instead of test sample only saline was added to the control test tube. Acetylsalicylic acid and diclofenac sodium were used as standard drugs. All the centrifuge tubes containing reaction mixture were incubated in a water bath at $56^{\circ} \mathrm{C}$ for $30 \mathrm{~min}$. At the end of the incubation the tubes were cooled under running tap water. The reaction mixture was centrifuged at $2500 \mathrm{rpm}$ for 5 min and the absorbance of the supernatants was measured at $560 \mathrm{~nm}$. The experiment was performed in triplicate for all the test samples. ${ }^{19,20}$

The percentages of hemolysis and protection were calculated according to the following formula:

Hemolysis $\%=($ Optical density of test sample/Optical density
of control $) \times 100$
Protection $\%=100-[$ (Optical density of test sample/Optical
density of control $) \times 100]$

\section{RESULTS}

The antimicrobial activity of the methanol extracts and $n$-hexane, chloroform, ethyl acetate, and water fractions of Lathyrus species is shown in Table 2 . The results indicated that the water and $n$-hexane fractions of $L$. cilicicus showed no activity against the tested microorganisms. Methanol extract was effective against $C$. albicans and the chloroform fraction was effective against $C$. albicans and $P$. aeruginosa. While the water fraction of $L$. armenus showed no activity, the methanol extract and $n$-hexane and chloroform fractions showed activity against $C$. albicans. The methanol extract and $n$-hexane and chloroform fractions of L. laxiflorus showed activity against $C$. albicans, and the water fraction of $L$. laxiflorus was found effective against $B$. subtilis. The methanol extract and $n$-hexane and chloroform fractions of $L$. aureus showed activity against $C$. albicans; additionally the water fraction of $L$. aureus was found effective against $B$. subtilis. The methanol extract of $L$. pratensis was effective against $C$. albicans and the chloroform fraction was effective against $C$. albicans and $P$. aeruginosa; additionally the water fraction of $L$. pratensis was found effective against $B$. subtilis. Ethyl acetate fractions of all studied Lathyrus species were effective against all tested microorganisms. The antimicrobial effect of the plant extracts against the microorganisms may have been due to the secondary metabolites content of these extracts, like phenolic compounds and saponin, which are reported to be antimicrobial. ${ }^{3}$ There are 
not many reports of research on the antibacterial screening of Lathyrus species. According to the literature, from butanolic extracts of $L$. aphaca seeds two triterpenoid saponins were isolated that showed antifungal activity against Colletotrichum dematium and Alternaria alternata. ${ }^{21}$ Inhibition of growth of Xanthomonas campestris pv. citri by L. odoratus L. and L. sativus L. seed extracts was studied. While L. odoratus showed no

Table 2. MIC values $(\mathrm{mg} / \mathrm{mL}$ ) of the examined Lathyrus species against the tested microorganisms

Microorganisms

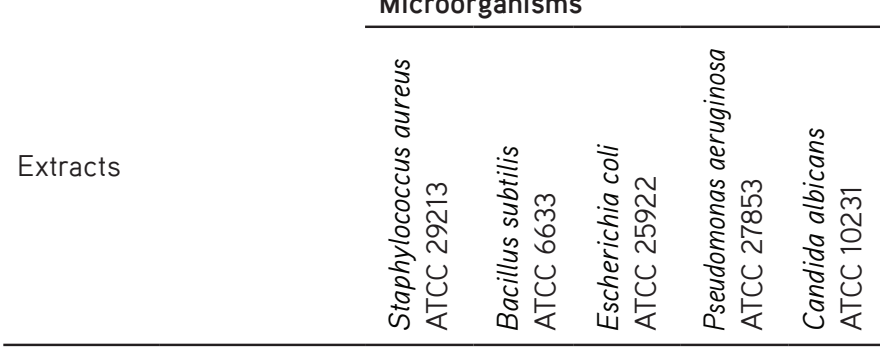

\begin{tabular}{|c|c|c|c|c|c|c|}
\hline \multirow{5}{*}{$\begin{array}{l}\text { Lathyrus } \\
\text { armenus }\end{array}$} & Chloroform & - & - & - & - & 0.5 \\
\hline & $n$-Hexane & - & - & - & - & 1 \\
\hline & Water & - & - & - & - & - \\
\hline & Ethyl acetate & 0.5 & 0.5 & 0.5 & 0.5 & 0.5 \\
\hline & Methanol & - & - & - & - & 1 \\
\hline \multirow{5}{*}{$\begin{array}{l}\text { Lathyrus } \\
\text { aureus }\end{array}$} & Chloroform & - & - & - & - & 0.5 \\
\hline & $n$-Hexane & - & - & - & - & 1 \\
\hline & Water & - & 1 & - & - & - \\
\hline & Ethyl acetate & 1 & 0.5 & 0.5 & 0.5 & 0.5 \\
\hline & Methanol & - & - & - & - & 1 \\
\hline \multirow{5}{*}{$\begin{array}{l}\text { Lathyrus } \\
\text { cilicicus }\end{array}$} & Chloroform & - & - & - & 1 & 0.5 \\
\hline & $n$-Hexane & - & - & - & - & - \\
\hline & Water & - & - & - & - & - \\
\hline & Ethyl acetate & 1 & 0.5 & 0.5 & 0.5 & 0.5 \\
\hline & Methanol & - & - & - & - & 1 \\
\hline \multirow{5}{*}{$\begin{array}{l}\text { Lathyrus } \\
\text { laxiflorus } \\
\text { subsp. } \\
\text { laxiflorus }\end{array}$} & Chloroform & - & - & - & - & 0.5 \\
\hline & $n$-Hexane & - & - & - & - & 1 \\
\hline & Water & - & 1 & - & - & - \\
\hline & Ethyl acetate & 1 & 0.5 & 0.5 & 1 & 0.25 \\
\hline & Methanol & - & - & - & - & 1 \\
\hline \multirow{5}{*}{$\begin{array}{l}\text { Lathyrus } \\
\text { pratensis }\end{array}$} & Chloroform & - & - & - & 1 & 0.5 \\
\hline & $n$-Hexane & - & - & - & - & 1 \\
\hline & Water & - & 1 & - & - & - \\
\hline & Ethyl acetate & 0.5 & 0.5 & 0.5 & 0.5 & 0.5 \\
\hline & Methanol & - & - & - & - & 1 \\
\hline
\end{tabular}

-: No activity, MIC: Minimum inhibitory concentration antibacterial activity, the mean inhibition zone of $L$. sativus seed extract was $1.16 \mathrm{~mm} .^{22}$ The antifungal activity of ethanolic extract and dichloromethane and water fractions of L. pratensis was expressed as MICs against C. albicans, Aspergillus fumigatus, and Aspergillus niger. ${ }^{23}$ Methanol and ethanol extracts of the leaf and body of $L$. karsianus showed antibacterial activity against Klebsiella pneumoniae, P. aeruginosa, S. aureus, Staphylococcus epidermidis, Bacillus cereus, Salmonella enteritidis, Proteus mirabilis, E. coli, and Enterococcus faecalis. ${ }^{24}$ Butanolic extract of the seeds of $L$. ratan and $L$. aphaca was investigated for antibacterial screening. The maximum inhibition was shown by $L$. ratan against $S$. aureus. As reported $L$. ratan extract was more active than L. aphaca. ${ }^{25}$ The antimicrobial activity of isolated anthocyanins and the ethanolic extract of $L$. odoratus were tested by disc diffusion assay against $S$. aureus, E. coli, Bacillus subtilis, Aspergillus niger, and C. albicans. ${ }^{26}$

In the study by Heydari et al., ${ }^{27}$ the antioxidant activities of these species were investigated by DPPH radical scavenging. In that study, different extracts of Lathyrus species exhibited significant free radical scavenging activity. The highest antioxidant activity was seen in L. laxiflorus subsp. laxiflorus. As seen in Table 3, L. laxiforus subsp. laxiflorus and L. pratensis have the highest contents of flavonoids. Recent studies showed that flavonoids possess antioxidant, anti-inflammatory, antinociceptive, and cytostatic properties due to their effects on the prostaglandin pathway. ${ }^{28}$ Therefore, they are effective in reducing oxidative stress and acute inflammation. The human red blood cell (HRBC) membrane is analogous to the lysosomal membrane. Therefore, HRBC membrane stabilization has been used as a method to study in vitro anti-inflammatory effects..$^{29}$ During inflammation neutrophils and monocytes are impaired or destroyed, resulting in release of lysosomal enzymes. ${ }^{30}$ Stabilization of the membrane suggests that the extracts might stabilize lysosomal membranes. Most anti-inflammatory drugs show their effects either by stabilizing the lysosomal membranes or inhibiting lysosomal enzymes. Moreover, several studies indicate that herbal products and plants could be effective in stabilizing the red blood cell membrane against hypotonicity, heat, or chemicals. ${ }^{31}$ Therefore, stabilization of the HRBC membrane was studied for further establishing the mechanism of the anti-inflammatory action of different extracts and fractions of Lathyrus species. The anti-inflammatory activity of the methanol extracts and $n$-hexane, chloroform, ethyl acetate, and water

\section{Table 3. Total flavonoid contents of methanolic extracts of the} examined Lathyrus species

\begin{tabular}{ll} 
Species & $\begin{array}{l}\mu \mathrm{g}_{\text {Quercetin }} / \mathrm{mg}_{\text {extracts }} \pm \\
\text { standard deviation }\end{array}$ \\
\hline Lathyrus armenus & $55.6 \pm 0.75$ \\
\hline Lathyrus aureus & $90.9 \pm 0.84$ \\
\hline Lathyrus cilicicus & $36.2 \pm 1.32$ \\
\hline Lathyrus laxiflorus subsp. laxiflorus & $105.4 \pm 2.38$ \\
\hline Lathyrus pratensis & $105.3 \pm 2.68$ \\
\hline
\end{tabular}

Each value represents mean \pm standard deviation 
fractions of Lathyrus species was investigated using HRBC membrane stabilization. Most of the extracts and fractions at a concentration of $2 \mathrm{mg} / \mathrm{mL}$ showed protective effects on human erythrocyte membranes against lysis induced by heat as shown in Table 4. In comparison to the other fractions and extracts, water fractions showed higher activity. Furthermore, the maximum membrane stabilization effect was observed for

Table 4. Protection and hemolysis percentage of the examined Lathyrus species on the human red blood cell (HRBC) membrane stability method

\begin{tabular}{|c|c|c|c|}
\hline \multirow{2}{*}{\multicolumn{2}{|c|}{ Extracts }} & \multicolumn{2}{|c|}{ Human red blood cell } \\
\hline & & Hemolysis \% & Protection \% \\
\hline & & \multicolumn{2}{|c|}{ Concentration $(2 \mathrm{mg} / \mathrm{mL})$} \\
\hline \multirow{2}{*}{\multicolumn{2}{|c|}{$\begin{array}{l}\text { Control (distilled water) } \\
\text { Control (isosaline) }\end{array}$}} & 100 & - \\
\hline & & 100 & - \\
\hline \multirow{5}{*}{ Lathyrus armenus } & Chloroform & $87.85 \pm 0.004^{*}$ & $12.14^{*}$ \\
\hline & $n$-Hexane & $99.85 \pm 0.005$ & 0.14 \\
\hline & Water & $17.20 \pm 0.006^{*}$ & $82.79^{\star}$ \\
\hline & Ethyl acetate & $24.65 \pm 0.004^{*}$ & $75.34^{*}$ \\
\hline & Methanol & $43.23 \pm 0.001^{*}$ & $56.76^{*}$ \\
\hline \multirow{5}{*}{ Lathyrus aureus } & Chloroform & $74.47 \pm 0.017^{*}$ & $25.52^{*}$ \\
\hline & $n$-Hexane & $86.84 \pm 0.002^{*}$ & $13.15^{\star}$ \\
\hline & Water & $19.16 \pm 0.002^{*}$ & $80.83^{*}$ \\
\hline & Ethyl acetate & $23.86 \pm 0.009 *$ & $76.13^{\star}$ \\
\hline & Methanol & $38.03 \pm 0.005^{\star}$ & $61.96^{*}$ \\
\hline \multirow{5}{*}{ Lathyrus cilicicus } & Chloroform & $62.40 \pm 0.003^{*}$ & $37.59^{*}$ \\
\hline & $n$-Hexane & $97.90 \pm 0.022$ & 2.09 \\
\hline & Water & $18.72 \pm 0.004^{*}$ & $81.27^{\star}$ \\
\hline & Ethyl acetate & $22.41 \pm 0.005^{\star}$ & $77.58^{*}$ \\
\hline & Methanol & $27.62 \pm 0.003^{*}$ & $72.37^{\star}$ \\
\hline \multirow{5}{*}{$\begin{array}{l}\text { Lathyrus laxiflorus } \\
\text { subsp. laxiflorus }\end{array}$} & Chloroform & $75.05 \pm 0.003^{*}$ & $24.94^{*}$ \\
\hline & $n$-Hexane & $91.03 \pm 0.003^{*}$ & $8.96^{*}$ \\
\hline & Water & $14.09 \pm 0.004^{*}$ & $85.90^{*}$ \\
\hline & Ethyl acetate & $21.25 \pm 0.006^{*}$ & $78.74^{*}$ \\
\hline & Methanol & $17.64 \pm 0.003^{\star}$ & $82.35^{*}$ \\
\hline \multirow{5}{*}{ Lathyrus pratensis } & Chloroform & $97.68 \pm 0.014$ & 2.313 \\
\hline & $n$-Hexane & $99.78 \pm 0.001$ & 0.216 \\
\hline & Water & $12.07 \pm 0.004^{*}$ & $87.92^{*}$ \\
\hline & Ethyl acetate & $18.72 \pm 0.004^{*}$ & $81.27^{*}$ \\
\hline & Methanol & $30.22 \pm 0.003^{*}$ & $69.77^{\star}$ \\
\hline \multicolumn{2}{|l|}{ Acetylsalicylic acid } & $12.74 \pm 0.37^{\star}$ & $87.25 \pm 0.37^{*}$ \\
\hline \multicolumn{2}{|l|}{ Diclofenac sodium } & $12.14 \pm 0.02^{*}$ & $87.85 \pm 0.02^{*}$ \\
\hline
\end{tabular}

Each value represents mean \pm standard deviation

*Statistically significant as compared to controls, $p<0.05$ (one-way ANOVA). the water fraction of $L$. pratensis (88\%) among all the extracts, followed by L. laxiflorus (86\%), methanol extract of L. laxiflorus, $L$. armenus (83\%), and $L$. aureus (81\%). Methanol extract of $L$. laxiflorus showed the maximum membrane stabilization effect (82\%) among the methanol extracts. Acetylsalicylic acid and diclofenac sodium were used as standard drugs and showed almost $87 \%$ protection at a concentration of $2 \mathrm{mg} / \mathrm{mL}$.

\section{DISCUSSION}

Most Lathyrus species are consumed as a food by animals and humans. In spite of this, there is not enough biological activity research on Lathyrus taxa. The aim of our study was to investigate the antimicrobial and anti-inflammatory activities of L. armenus, L. aureus, L. cilicicus, L. laxiflorus subsp. laxiflorus, and $L$. pratensis. According to the results, ethyl acetate fractions were more effective than the other extracts and fractions against the test microorganisms. Our results also revealed that different extracts and fractions of the examined Lathyrus species possessed anti-inflammatory properties. The methanol extracts and water fractions exhibited membrane stabilization by inhibiting heat-induced lysis of the erythrocyte membrane more than the others. The water fraction of $L$. pratensis showed the maximum activity (almost equal to the standard drugs) among all of the fractions of the examined Lathyrus species.

\section{CONCLUSIONS}

Lathyrus species are consumed as a food by animals and humans, but there is not enough biological activity research about Lathyrus. Thus the aim of this study was to investigate the antimicrobial and anti-inflammatory activities of Lathyrus species, two of which are endemic for Turkey. According to the results ethyl acetate fractions were more effective than the other extracts and fractions against gram-positive and gramnegative bacteria and fungi. Our results also revealed that different extracts and fractions of Lathyrus species possessed anti-inflammatory properties. The methanol extracts and water fractions exhibited membrane stabilization by inhibiting heatinduced lysis of the erythrocyte membrane more than the others. The water fraction of $L$. pratensis showed the maximum activity (almost equal to the standard drugs) among all of the fractions. In conclusion, these experimental results indicate that the membrane stabilizing effect of the various extracts and fractions of the Lathyrus species is primarily due to the active phytoconstituents (i.e., flavonoids) in the plant, which seems to support the use of this plant in traditional medicine. In this regard, isolation from Lathyrus species is proceeding simultaneously in our laboratory. To the best of our knowledge, this is the first study evaluating the membrane stabilizing activity of Lathyrus species growing in Sivas, Turkey. However, further studies are needed to evaluate the exact mechanism and responsible substances of these activities.

Conflict of Interest: No conflict of interest was declared by the authors. 


\section{REFERENCES}

1. Lewis GP, Schrire B, Mackinder B, Lock M. Legumes of the World. Edinb J Bot. 2005;3:195-196.

2. Davis PH. Flora of Turkey and the East Aegean Islands. Edinburgh University Press; Edinburgh;1970:325-354.

3. Cowan MM. Plant products as antimicrobial agents. Clin Microbiol Rev. 1999;12:564-582.

4. Bhalodia NR, Shukla V. Antibacterial and antifungal activities from leaf extracts of Cassia fistula l.: An ethnomedicinal plant. J Adv Pharm Technol Res. 2011;2:104-109.

5. Hammer KA, Carson C, Riley T: Antimicrobial activity of essential oils and other plant extracts. J Appl Microbiol. 1999;86:985-990.

6. Libby P. Inflammatory mechanisms: the molecular basis of inflammation and disease. Nutr Rev. 2007;65:140-146.

7. Dinarello CA. Anti-inflammatory agents: present and future. Cell. 2010;140:935-950

8. Singh R, Patil S, Pal G and Ahmad M. Evaluation of in vivo and in vitro anti-inflammatory activity of Ajuga bracteosa Wall ex Benth. Asian Pac J Trop Dis. 2012;2:404-407.

9. Aruoma Ol. Free radicals, oxidative stress and antioxidants in human health and disease. J Am Oil Chem Soc. 1998;75:199-212.

10. Kris-etherton PM, Lefevre M, Beecher GR. Bioactive compounds in nutrition and health-research methodologies for establishing biological function. the antioxidant and anti-inflammatory effects of flavonoids on atherosclerosis. Annu Rev Nutr. 2004;24:511-538.

11. Choei HR, Choi JS, Han YN, Bae SJ, Chung HY. Peroxynitrite scavenging activity of herb extracts. Phytother Res. 2002;16:364-367.

12. Lobo V, Patil A, Phatak A, Chandra N. Free radicals, antioxidants and functional foods: Impact on human health. Pharmacogn Rev. 2010;4:118126.

13. Cui XY, Kim JH, Zhao X, Chen BQ, Lee BC, Pyo HB, Yun YP, Zhang $\mathrm{YH}$. Antioxidative and acute anti-inflammatory effects of Campsis grandiflora flower. J Ethnopharmacol. 2006;103:223-228.

14. Kim SH, Song YS, Kim SK, Kim BC, Lim CJ, Park EH. Anti-inflammatory and related pharmacological activities of the $\mathrm{n}-\mathrm{BuOH}$ subfraction of mushroom Phellinus linteus. J Ethnopharmacol. 2004;93:141-146.

15. Nagaharika Y, Rasheed S. Anti-inflammatory activity of leaves of Jatropha gossypifolia L. by HRBC membrane stabilization method. J Acute Dis. 2013;2:156-158

16. Ferraro MJ, Swenson JM. Methods for dilution antimicrobial susceptibility tests for bacteria that grow aerobically, Approved standard, (8th ed). Clinical and Laboratory Standards Institute. 2009;29:15-18.

17. Karunai Raj M, Balachandran C, Duralpandiyan V, Agastian P, Ignacimuthu S. Antimicrobial activity of Ulopterol isolated from Toddalia asiatica (L.) Lam: A traditional medicinal plant. J Ethnopharmacol. 2012;140:161-165

18. Bag GC, Grihanjali P, Bhaigyabati TH. Assessment of total flavonoid content and antioxidant activity of methanolic rhizome extract of three Hedychium species of manipur valley. Int J Pharm Sci Rev Res. 2015;30:154-159.

19. Sakat S, Juvekar AR, Gambhire MN. In vitro antioxidant and antiinflammatory activity of methanol extract of Oxalis corniculata Linn. Int J Pharm Pharm Sci. 2010;2:146-155.

20. Shinde U, Phadke A, Nair A, Mungantiwar A, Dikshit V, Saraf M. Membrane stabilizing activity a possible mechanism of action for the anti-inflammatory activity of Cedrus deodara wood oil. Fitoterapia. 1999;70:251-257.

21. Khan NA. Two antifungal active triterpenoid saponins from the seeds of Lathyrus plants. Nat Prod Res. 2011;25:1687-1694.

22. Aktar MA, Rahber-Bhatti M, Aslam M. Antibacterial activity of plant diffusate against Xanthomonas campestris pv. citri. Int Pest Manage. 1997:43:149-153.

23. Arabi Z, Sardari S. An investigation into the antifungal property of Fabaceae using boinformatics tools. Avicenna J Med Biotechnol. 2010;2:93-100.

24. Özkan OA, Adıgüzel MC, Erdağ D, Bağcigil AF and Aydin H. In Vitro comparison of the antibacterial activity of extracts from endemic plants species. J Ayu Med Sci. 2014;4:1608-1614.

25. Khan NA, Quereshi S, Pandey A and Srivastava A. Antibacterial Activity of Seed Extracts of Commercial and Wild Lathyrus Species. Turkish J Biol. 2009;33:165-169.

26. Mohamed S. Anthocyanins and fatty acids from the flowers of Lathyrus odoratus L. and their antimicrobial activity. Planta Med. 2009;75:175.

27. Heydari H, Saltan GS, Acikara ÖB, Yilmaz S, Çoban T, Tekin M. Antioxidant Activity of five Lathyrus species growing in Turkey. Turk $J$ Pharm Sci. 2015;12:369-376.

28. Diniz TC, Silva JC, De Lima-Saraiva SR, Ribeiro FP, Pacheco AG, De Freitas RM, Quintans-Junior LJ, Quintans JDES, Mendes RL, Almeida JR. The role of flavonoids on oxidative stress in epilepsy. Oxid Med Cell Longev. 2015;2015:1-9.

29. Anosike CA, Obidoa O, Ezeanyika LU. Membrane stabilization as a mechanism of the anti-inflammatory activity of methanol extract of garden egg. DARU. 2012;20:76-83.

30. Barkley JR, Myers CM. Practice Guidelines for acute Care Nurse Practitioners, (2nd ed). USA; Saunders Elsevier Health Sciences; 2007:50.

31. Mariappan G, Saha BP, Sutharson L, Singh A, Garg S, Pandey L, and Kumar D. Analgesic, anti-inflammatory, antipyretic and toxicological evaluation of some newer 3-methyl pyrazolone derivatives. Saudi Pharm J. 2011;19:115-122. 